\title{
Risk Technologies and the Securitization of Post-9/11 Citizenship: The Case of National ID Cards in Canada
}

\author{
Kevin Walby Carleton University \\ Sean P. Hier University of Victoria
}

\begin{abstract}
Résumé
Les attaques du 11 septembre 2001 sur Washington et New York continuent d'influencer la manière dont les gouvernements gèrent les déplacements de personnes, l'immigration, la citoyenneté et la sûreté nationale. Au Canada, suite aux événements du 11 septembre, l'une des plus contentieuses mesures envisagées en vue de garantir la sûreté nationale a été d'introduire une carte d'identité nationale biométrique. Dans cette communication, nous soutenons que l'effort en vue d'introduire une carte d'identité nationale biométrique est lié à un raisonnement idéologique qui menace d'exacerber plutôt que d'apaiser les sentiments d'insécurité nationale quant aux risques, à la citoyenneté et à la sûreté des frontières. Nous maintenons que les technologies de contrôle de « preuve de statut », telles que les cartes d'identité encodées biométriques, conduisent à la " tritisation » de la citoyenneté et nous concluons que - au nom de la sûreté nationale - ces cartes d'identité risquent de déstabiliser les spatialisations modernes de la souveraineté qu'elles sont censées protéger.
\end{abstract}

\begin{abstract}
The attacks of 11 September 2001 on Washington and New York continue to influence how governments manage im/migration, citizenship, and national security. One of the more contentious national security responses to the events of 9/11 in Canada has been the drive to introduce a biometric national identification card. In this paper, we argue that the drive for a Canadian national ID card is bound up in ideological processes which threaten to exacerbate, rather than to alleviate, state insecurities pertaining to risk, citizenship, and border (in) security. We maintain that 'proof of status' surveillance technologies, such as biometrically-encoded ID cards, lead to the 'securitization' of citizenship, and we conclude that ID cards threaten to destabilize the modern spatializations of sovereignty that they are purported to uphold under the guise of national security.
\end{abstract}




\begin{abstract}
Today, instead of an either-or, we face a this-as-well-as-that world: national security is no longer national security; foreign and domestic policy, national security and international cooperation are now interlocked. Not only have the walls between inside and outside, military and police, secret service and police been torn down, but also the walls between innocent and guilty persons, those under suspicion and those not under suspicion, where previously the law had made a very strict and clear distinction. Under conditions of a universalized perception of terrorist threats all individuals and individual rights are transformed into a risk to the state (Beck, Bonss and Lau 2003:18).
\end{abstract}

\title{
Introduction
}

The intensification of national security measures following the events of 11 September 2001 (hereafter "9/11") has increased the prevalence of state-driven surveillance projects globally. In some respects, post-9/11 surveillance projects indicate the continuing sovereign capacities of the nation-state, albeit in the context of new configurations of citizenship and surveillance. Surveillance technologies that have hitherto been limited in scope and application (e.g. networked public/private databases, automated monitoring systems, biometric identifiers) proliferated in Canada and elsewhere after 9/11, and they continue to exercise a strong influence on the ways in which citizen-subjects are identified, processed, incorporated, and excluded. While the securitization of citizenship is occurring in a worldwide policy environment driven by the American government's preoccupation with 'border harmonization', the international promotion and proliferation of new state surveillance measures are also occurring in a media-amplified culture of suspicion, insecurity, and fear.

Securitization refers to a complex sequence of relations and social processes, whereby nation-states attempt to fortify their borders against external threats while 'purging the inside' by intensifying the use of risk technologies and surveillance techniques. Biometric national ID cards are one material manifestation of the drive for the securitization of citizenship after 9/11. Aided by computerization and networked integration, biometric technologies are generally purported to be an effective governing tool based on their ability to connect individuals and groups to centers of power and information (Zureik and Hindle, 2004). Although the protection of Canadian political clout in the post-9/11 security environment is a component of the Canadian government's international agenda, the drive to introduce biometric technologies has been reinforced by a series of legislative acts aimed at harmonizing national security practices in Canada and the U.S.A. ${ }^{1}$ However, unlike public policy debate in the UK, which has witnessed the approval of the first stages of ID card adoption, the drive for a national ID card in Canada has stalled in part because

${ }^{1}$ Bill C-36 and Securing an Open Society: Canada's National Security Policy in Canada (Privy Council Office of the Government of Canada, 2004), US-Canada Smart Border/ 30 Point Action Plan Update (The White House, 2001), the PATRIOT Act (2001), National Intelligence Reform Act of 2004 (2004), and the 9/11 Recommendations Implementation Act (2004) in the U.S.A. 
efforts to introduce ID cards in the U.S.A. have met with resistance.

In this paper, we examine some of the ways that access to citizenship rights has been mediated and compromised by securitization after $9 / 11$. As a component of the 'War on Terror' abroad, locating enemies within the state is a principal motivation for securitization - as it has always been in wartime practice (Schulhofer, 2002; Muller, 2004). If state apparatuses can see and know all 'inside the state' by regulating the movement of citizens and non-citizens across borders, the inside can be eliminated as a threat to national security. Intensified surveillance measures not only imperil the ethos of citizenship; proof of status surveillance devices may also jeopardize the notion of sovereignty that underpins the modern political epoch.

In the first section of the paper, we consider the contemporary nature of surveillance. We assess the impact of $9 / 11$ on state surveillance practices, as well as the concomitant proliferation of biometric risk technologies as a means of state governance. In the second section, we situate the drive for a national ID card in Canada in the context of international trends, and we demonstrate how the politics and the dynamics of state surveillance operate within the post-9/11 context. In the final section, we address the relationship between citizenship and surveillance. Our concern is not with the content(s) of citizenship rights, but rather with access to rights and how they are mediated by the advent and implementation of new surveillance technologies. While biometric national ID cards and other proof-of-status technologies act as a means of ensuring that bona fide state citizens are afforded access to their rights, they also work to exclude non-citizens, to increase formal surveillance measures, and to limit distribution of citizenship rights in the context of neo-liberal social expenditure restraints.

\section{Surveillance, Social Control, Securitization, and Biometrics}

In one of the most influential statements on the character of social monitoring, Max Weber (1968; 1983) differentiated administrative-based societies from the more scientific- and technological-based ones emerging in the early twentieth century. He identified social engineering techniques as intrinsically bound to the ascendancy of the modern capitalist economy. Social administration, for Weber, was a product of the rationalization processprocedural, bureaucratic means to carry out rules of legitimacy and legal authority. Prioritizing the function of paper dossiers in the administration of the nation state, Weber understood the accumulation and centralization of information about embodied persons as fundamental to the execution of state power.

Whereas Weber located the surveillance function within discrete files comprised of information on the citizenry, the proliferation of computerized data banks has increasingly facilitated the storage, distribution, and sharing of information across state and extra-state 
agencies. The result has been that once highly restricted administrative information and data gathering systems comprised of personal paper files have converged, to the extent that administrative dossiers today coalesce with genetic, biometric, and visual body data through networked systems that exchange only select pieces of information for a plethora of reasons. Combined with the growing number of organizations that are intensifying surveillance practices in an effort to maximize productivity, the embodied human agent, and thus the personalized dossier, has increasingly become an adjunct to governmental regulation. What has emerged in its place is a series of abstracted data images, categorical representations or 'risk profiles', which function to classify and sort populations on the basis of available and exploitable personal information.

Made possible by the digitalization of personal information, processes of rationalization have increasingly morphed into automated surveillance practices (Lyon, 2003a). Implicated in this set of processes has been a decline in the importance of the physical copresence of human agents, supplemented if not replaced by tokens of trust or authentication such as bar codes, magnetic strips, PIN numbers, and passports that serve to classify and categorize 'data subjects' on the basis of socio-economic status, credit history, or insurance coverage (Lyon, 2001). Not only does this demarcate a conceptual point of distinction from old bureaucratic organizational infrastructures, but it also simultaneously denotes an underlying continuity with those structures based on the desire to maximize organizational efficiency and manage contingency. Given the dispersion of the sites of surveillance, then, the primary difference of contemporary surveillance capabilities is not to be located exclusively in intensified forms of centralized administration vis-à-vis digitally-based forms of rationalization; rather, a series of integrations involving otherwise dispersed fragments of information have come together across a range of social locations for a myriad of reasons.

In light of the fact that social categorizations are to an increasing extent created on the basis of personal information that circulates through networked infrastructures, recent contributions to the surveillance literature have sought to break from the argument that monitoring involves powerful and centralized top-down forms of social control. Haggerty and Ericson (2000), for example, conceptualize surveillance in terms of an 'assemblage.' They explain that the 'surveillant assemblage' works by breaking the human body into a series of signifying data flows- small pieces of information, collected and stored in a large number of computer databanks, that are available for 'assemblage' by a growing number of agencies for an expanding number of reasons. The escalating number of information sources involved in contemporary surveillance activities - e.g. traces from internet activity, credit card use, and income tax records, as well as genetic, health, and policing data - allows for the circulation of information through loosely integrated public and private sector computer networks, to the extent that deliberate, top-down panoptic 
conceptions of surveillance fail to capture the complexity of present-day information gathering and data analysis. As technologically enhanced surveillance functions become a regular feature of everyday life, Haggerty and Ericson contend, the surveillant assemblage has worked to level previously existing surveillance hierarchies beyond the centralized (panoptic) state.

It is reasonable to argue that developments in contemporary surveillance capabilities have opened spaces not previously accessible to such a wide range of diverse agencies and organizations. Once discrete public and private-sector information storage systems have come into contact because of the increasingly porous character of information handling processes, to the extent that "no major population groups stand irrefutably above or outside the surveillant assemblage" (Haggerty and Ericson, 2000: 618). The problem with the assemblage model, however, is that it tends to suggest that centralized, asymmetrical forms of (state) surveillance are no longer important. As Hier (2003) has demonstrated, investigation into the expanding applications of networked surveillance systems cannot come at the expense of insights into new and more efficient possibilities for monitoring practices that exacerbate already existing social divisions in the context of unequal relations of power. In focusing social analyses primarily on the expanding technological capabilities of surveillance systems, critics run the risk of neglecting the social dimensions and the diverse human and material implications of surveillance techniques - how they are socially constructed, how they penetrate social groups differently, and how they can contribute to the intensification of social inequality.

To appreciate the importance of exploring this nexus of technological and social forces, consider the expanded range of surveillance functions introduced following 9/11. In the aftermath of the attacks on New York and Washington, policing powers were extended in technological realms such as wiretaps and web-based click-stream monitoring, and a range of other technological fixes appeared around the world to monitor larger numbers of people. Set in the context of claims to the terrorist threat, and reinforced by the repeated visual imagery of the collapsing Twin Towers, calls for preventative security measures and risk management techniques unleashed technological remedies in the form of iris scans, facial recognition software, smart cards, and DNA fingerprinting (Lyon, 2003a). Although constituted through an assemblage of technological flows of information which touched a cross-section of the population, the application of those technological flows was not only conceived of but unevenly applied along the socio-cultural lines of race, nationality, and geographic origin (e.g. Ahmad, 2002; Adelman, 2002; Lyon, 2003b; Williams, 2004).

\section{Surveillance After 9/11}

Following the intelligence failure and human catastrophe of $9 / 11$, the issue of national security made a hasty and pronounced return to policy agendas in the U.S.A, in Canada, 
and in Europe (Shearman and Sussex, 2004). Although the alleged risks posed by various ethno-cultural minorities and political groups contributed to the legitimizing of intensified state surveillance in the past (see Whitaker and Marcuse, 1994), the 'War on Terror' has ushered in restrictions on a new scale. In the rush towards securitization after 9/11, civil liberties have been eroded. Accountability safeguards have likewise been disassembled, leaving executive power unchecked and intrusive forms of surveillance with little or no judicial oversight (Schulhofer, 2002: 66) - and ultimately threatening democratic process itself (Gill, 2003; Huysmans, 2004). Most alarming, we have witnessed the erosion of the distinction among law enforcement, intelligence gathering, and national security practices (Whitaker, 2005). Citizens' personal information is increasingly shared between agencies willing, able, or forced ${ }^{2}$ to merge databases. In the name of national security and antiterrorism, too, clandestine searches by state agencies effectively provide information to state security agencies.

State borders are symbolic spatializations of modern sovereignty and a site foremost of new national security practices. Caught up in the intensification of data gathering and analysis after 9/11, state surveillance practices have led to a reconstitution of the way borders operate (Biersteker, 2003). In one sense, the 'border is now everywhere,' or 'delocalized,' such that the international political distinction between inside and outside is less explicit (Lyon, 2003a: 147). In a second sense, 9/11 has led to a securitization of the inside (Muller, 2004) that simultaneously alters and reinforces the distinction between inside/outside. As Beck et al (2003:10) put it, "the state is back," and for the oldest Hobbesian reason - the provision of security in world risk society.

For the U.S. government and, to a lesser extent, the Canadian government, information is a key weapon in the 'War on Terror'. Issues of im/migration and asylum have moved to center stage in international politics (Stevens, 2001), and novel forms of keeping track of incomers and out-goers are being devised to catalogue and verify identities. Biometric identification measures - face, fingerprint, and eye recognition software, for examplecomprise one set of technological capabilities to achieve these ends. Biometric devices are systems of automatic identity authentification that utilize unique physiological characteristics like fingerprint, face, and retinal features. Since 9/11, the production and deployment of biometrics have accelerated (Czegledy and Czegledy, 2002). On the surveillance horizon, it appears imminent that biometric technologies will be applied at many points of access, especially at border crossings. In the U.S. - Canada Smart Border/30 Point Action Plan ${ }^{3}$ enacted by former Homeland Security Secretary Tom Ridge and former deputy Prime Minister John Manley in December, 2001, the implementation

${ }^{2}$ Lowering the threshold of what is a 'significant purpose' to conduct searches and seizures, the USA PATRIOT Act (2001) grossly widens the powers of intelligence-gathering agencies in the U.S.A. Email and telephone communications can be traced on the basis of suspicion, business records may be seized without warrants, and any number of personal records ranging from library transactions to car rentals may be collected. 
of biometric identification technologies tops the list. The act reads:

\begin{abstract}
The United States and Canada have agreed to develop common standards for the biometrics that we use and have also agreed to adopt interoperable and compatible technology to read these biometrics. In the interest of having cards that could be used across different modes of travel, we have agreed to use cards that are capable of storing multiple biometrics (The White House, 2001).
\end{abstract}

In its first comprehensive statement on national security issues, Securing an Open Society (Privy Council Office of the Government of Canada, 2004: 44), the Canadian government asserted its intention to complete the Smart Border Action Plan and to apply smart border principles around the world. The Securing an Open Society document also reveals the Canadian government's intention to begin issuing a biometric-enabled smart chip passport in 2005. This passport initiative, however, does not prevent the government from implementing additional and overlapping 'proof-of-status' technologies in the future.

Risk technologies like biometrics facilitate the expedient collection, instantaneous transfer, and wider control of personal information. Towards the end of his life, Michel Foucault (1978) began to conceive of politics in terms of biopower. Biopower is a power exercised over a whole population so that individuality is constitutionally imbricated with state management practices. Biopower marks a transformation of the state, which replaces state power over death with the power of surveillance, classification, and sorting. Thus, biopower is a power 'to make live and let die' which draws upon the anatomical characteristics of the subject population being administered. Foucault's genealogical method preempted him from making anything but antiquated claims about information technologies, but the rise of biometrics in some ways vindicates Foucault's thesis about the relationship between the body and the state. New biometric technologies are increasingly utilized to verify identity and shape mobility inside and outside zones of inclusion and exclusion (of which the state is certainly one). That biometrics have fast become a staple of security policy speaks to how securitization has penetrated the minds of policy makers, but also suggests the degree to which the bodies of the body politic are increasingly employed as an instrument of governance over and against themselves.

To illustrate how new surveillance technologies can utilize biometric capabilities within the context of the state regulation of people and information flows, we examine the drive for a Canadian national ID card. Although 9/11 provided a new impetus for ID cards

\footnotetext{
${ }^{3}$ In 1995, former Prime Minister Chrétien and former President Clinton signed an accord entitled Our Shared Border (1995) that largely set the policy groundwork for another part of the U.S. - Canada Smart Border/30 Point Action Plan declaration of 2001 - the so-called 'safe third country provision' (The White House, 2001). What the declaration achieves in this regard is the significant reduction of Canadian refugee claimants passing through the U.S.A, because claimants must declare refugee status in the first country. Otherwise, claimants will be turned back at each subsequent border they try to cross.
} 
around the world, the push to augment surveillance systems and introduce ID cards in many countries predated the events of $9 / 11$ by a decade or more. Although they are not the only possible technology that may be utilized in the future, nation-states around the world have implemented national ID cards, and many others have plans to do so (see below). There are key analytical distinctions to be made between, biometric national ID cards and smart chip passports, for instance, but conceptualizing securitization as an inherently ideological process allows for all new forms of state surveillance to be exposed as latent national security practices. Because these practices are ideological, and because the purpose of 'proof-of-status' technologies is to verify identification in relation to the state, the debate over, and potential deployment of, biometric national ID cards in Canada presents real, material implications for citizenship, social justice, and human rights.

\section{Biometrics, International Securitization, and the National ID Card in Canada}

Governments and technology sectors have shown recurring interest in national identity cards to improve domestic security, to reduce fraud and identity theft, and to prevent 'illegal' im/migration (Lyon, 1993). Whereas smart chip passports operate more or less like paper-based passports, save for the introduction of biometric identifiers that makes forgery more difficult (but not impossible), national ID cards act as both internal and external devices of control. This implies that national ID cards could be used to enfaorce intermittent checks on human movement within the nation-state (Torpey, 2000:165), and that ID cards could apply to mobility beyond the nation-state and across international borders (i.e. mobility in the European Union). ID cards differ from passports in that they can also encode entitlement to certain political (i.e. voting) and social rights (i.e. welfare) (Stadler and Lyon, 2003). ID cards would replace entitlement cards and resident cards, incorporating the functions served by those cards into one device. Whether the card is voluntary or not in a given country depends on what other purposes it is used for (i.e. ID cards may incorporate medical information) and what other forms of identification are widely used (i.e. drivers licenses). Electronic cards enable more effective administration of personal data. ${ }^{4}$ Biometric cards are the ultimate in 'proof of status' technology, as identity is verified using one's own bodily features.

\footnotetext{
${ }^{4}$ The proponents of national ID cards are quick to remark the multiple benefits of such devices. For instance, in the conclusion to his book Card-Carrying Americans, Joseph W. Eaton (1986: 206) argues that national ID cards could allow for better access to governmental entitlement programs, could improve the equity of tax payments, could deter professional burglars, and could reduce the incidence of "fraud, misrepresentation, computer crime and terrorism". Likewise, Amitai Etzioni (1999, Chapter 4) argues that implementing ID cards would reduce criminality, child abuse and sex offenses, tax evasion, nonpayment of child support, illegal gun sales, illegal immigration, welfare fraud, identity theft, and credit card fraud. Such endorsements tend to see ID cards as a technological fix capable of solving all 'social problems' without acknowledging that all of these 'social problems' still occur in countries which have had tamper-proof national ID cards for decades. The benefits of new 'proof of status' technologies must be considered against drawbacks that could accompany their implementation.
} 
The ability of states to uniquely identify persons - citizens and non-citizens- "is at the heart of the process whereby states . . . have succeeded over time in monopolizing the legitimate means of movement in the modern world" (Torpey, 2000:17). In Britain, for instance, ID cards were temporarily introduced during the First and Second World Wars (Agar, 2001:101). Sixty years after the end of WWII, and despite an estimated cost of 3 billion pounds, the U.K. House of Commons has approved a National Identification Bill that eases the implementation of biometric national ID cards and poses serious implications for immigration procedures (see Privacy International, 2005). This current initiative began in 2003 when Home Office Secretary David Blunkett tried to introduce biometric national ID cards by issuing them with all new drivers licenses and/or passports (Times-Colonist, April 11, 2004, D4). The Home Office cited the prevention of illegal working and im/migration as top priorities (Home Office, 2004).

In other countries, ID cards serve drastically different functions. In the case of Rwandan genocide, those with "Tutsi" marked on their identity cards were generally killed (Longman, 2001:355). ID cards were used to dehumanize through categorization those oppressed in apartheid South Africa (Bowker and Star, 1999). Greece, which records religious affiliation on its national ID card, has been accused of discriminating against people who are not Greek Orthodox (The Gazette, November 21, 2003. A27). Trying to curtail rural to urban migration, China is pursuing an ID card program in which the vital information of all Chinese citizens will be made available to authorities anywhere in the country via a high-powered micro chip (Lyon, 2004). The ID card program may be used to reinforce China's Household Registration System, or hukou system, which has been used since the 1950s to control internal migration and privilege the official urban population (see also Treiman and Wu, 2004; Wang, 2004). Germany has had a compulsory ID card since 1987, but the existing card will soon be upgraded to include a biometric identifier. Malaysia began to introduce a multi-purpose 'smart' card in 2001 (Stadler and Lyon, 2003:81). Incorporating national ID, driver's license, passport information, and, potentially, health information in the future, the card has not yet been fully implemented. Hong Kong, Singapore, and Thailand each have hi-tech ID card systems (Stadler and Lyon, 2003).

National ID card initiatives have also failed, or been forestalled, in some countries. In 1996, for example, the South Korean government launched an electronic ID card campaign that would have seen forty-two items of personal data from six databases merged into a single device. Opposition groups protested the government's decision, and the government abandoned the project in 1999 (Kim, 2004: 208). The 'Australia Card', too, was defeated as excessive and potentially authoritarian in 1986 (Lyon, 2004). The Japanese government continues to experience civil disobedience over their proposed ID card (Lyon and Wood, forthcoming). In 1998, public protest halted a national ID card 
initiative in Taiwan (Stadler and Lyon, 2003: 81). And despite claims by Etzioni (1999) that biometrics ID cards are 'superior' and 'common-sense' forms of surveillance, the U.S.A. has yet to introduce a biometric ID card. However, the Office of Homeland Security, the American Association of Motor Vehicle Administrators, and the Justice Department are working to turn state drivers licenses into ID cards that would contain standardized data and security information linked to a national identification system (Stadler and Lyon, 2003: 82). Other countries, such as Italy and Finland, have had national ID cards for decades. Italy may soon upgrade its card and incorporate a digitized fingerprint identifier (House of Commons, 2003a: 38). Patterns of adoption and nonadoption vary depending on political, cultural, and economic factors.

\section{The Drive for a National ID Card in Canada}

In Canada, the drive for a national ID card system has progressed and stalled several times over the past decade. The idea originated in 1994 in Canada in the Canadian Passport Office, and it was recommended that the wallet-sized identity cards bear digital 'hand prints' and digital photographs. Scanning machines were to be implemented at customs and immigration counters. The national ID card would complement, rather than replace, the old passport system (Edmonton Journal, June 5, 1994, B4). Bypassing long immigration control lineups was identified as a key benefit. In 1995, then-Ontario Premier Mike Harris re-proposed the question of a biometric national ID card (Times-Colonist, July 15, 1995, A1), and in 1996 he proposed an 'Ontario card' to replace health cards, drivers licenses, welfare identification and seniors' cards (The Ottawa Citizen, February 14, 1996, A10). Then Privacy Commissioner of Canada Bruce Phillips argued that a provincial card conjured ideas of how Nazis used Dutch administration systems to locate and persecute Jewish persons during WWII (Toronto Star, July 14, 1995, A12).

In 1999, the Standing Committee on Human Resource Development considered a proposal entitled Beyond the Numbers: The Future of the Social Insurance Number System in Canada, which sought to replace the Canadian Social Insurance Number (SIN) with a biometric national identity card. SINs were designed as reference numbers for the Canada Pension Plan and for various employment programs in the 1960s. Today, SINs are necessary when filling out government forms and are sometimes requested when obtaining bank services, applying for employment, etc. Supporting the idea, and citing "the social insurance card scam," "the refugee scam," "the welfare scam," and the "health care scam" as serious social problems, Financial Post columnist Diane Francis argued that, unless Canada implemented "one card and a national computer system linking all government entitlement programs," it would continue to be "a sitting duck for the desperate and the desperado" (The Windsor Star, May 25, 1999, A8; National Post, April 24, 1999, D3). In the House of Commons, however, the government rejected the idea of issuing a new ID card with biometric identification, because the cost of issuing a biometric SIN card to over 
30 million potential users was estimated at somewhere between $\$ 1.2$ billion and $\$ 3.6$ billion (excluding periodic re-registration costs) (see House of Commons, 2003b).

In November 2002, then-Minister of Citizenship and Immigration Denis Coderre reintroduced the issue of biometric national ID cards to Canadians. Although identity theft and fraud were pushed as the big issues (Calgary Herald, February 6, 2003,A1), satisfying the American preoccupation with border securitization post-9/11 was the driving impetus. Replacing the citizen certificate card, Coderre purported, the new biometric national ID card would be modeled on the 'Maple Leaf' card. ${ }^{5}$ In the media, Coderre conflated biometric national ID cards with drivers' licenses in order to normalize the idea (National Post, November 15, 2002, A8). George Radwanski, then-Privacy Commissioner of Canada, argued that the card would move Canada towards authoritarianism (The Ottawa Citizen, March 19, 2003, A11). Coderre stressed that a debate was needed, and suggested that the House of Commons Standing Committee on Citizenship and Immigration was an appropriate forum. The Committee took up the task.

In July of 2003, while the Standing Committee was visiting six European capitals to collect information about national ID cards, EKOS Research Associates released a report showing that 7 out of 10 Canadians favored a biometric national ID card (EKOS, 2003; Edmonton Journal, July 27, 2003, A6). The extensive report, costing the Citizenship and Immigration department $\$ 93,500$, included telephone polling and focus groups held earlier that year. Support was noticeably lower in the Western provinces. A Pollara group poll in the same year claimed similar results (Public Policy Forum, 2003). Regarding the reports, however, it is not clear if Canadians had a strong understanding of exactly what biometrics do and the potential of biometrics to connect individuals and groups to centers of power and information (Zureik and Hindle, 2004: 132). The Standing Committee on Citizenship and Immigration doubted the usefulness of the EKOS report because it asked a number of leading questions.

The ideological underpinnings of the ID card as a national security project continued to resonate. Referencing national ID cards, Coderre told the media, "It's not about building walls; it's about controlling doors to make sure that people who are coming for the wrong

\footnotetext{
${ }^{5}$ In March 2002, the now infamous 'Maple Leaf' permanent resident card for landed immigrants was given life in a Standing Committee on Citizenship and Immigration report entitled Building a Nation: The Regulations under the Immigration and Refugee Protection Act (Building a Nation, 2002). The 'Maple Leaf' card is not a national ID card but is a 'proof of status' device illustrative of the relationship between surveillance and citizenship. Replacing the paper document used by landed immigrants, the 'Maple Leaf' card is a wallet-sized, plastic photo ID with a number of fraud-resistant features. The new card was ushered in by the federal government in response to pressure from the U.S.A. New immigrants in Canada would be issued the 'Maple Leaf' card as part of their landing process, as would other recent immigrants. The irony is that, despite the high cost of the 'Maple Leaf' card (which features information locked into a magnetic strip and embedded anti-duplication devices), the card was already being counterfeited two months after introduction and before the system was even fully implemented.
} 
reasons face the consequences" (Daily News, April 19, 2003, A2). Inter-discursively coupled with other speeches that spoke of "illegal im/migrants," Coderre's comments suggested that the majority of "non-Canadians" might be coming here for the "wrong reasons." There was still, however, a wave of opposition that Coderre would have to ride out if he was to see his ID card plan go through. As part of his race to be leader of the federal Liberal party, Paul Martin questioned the biometric national ID card initiative (The Windsor Star, July 25, 2003, B1). The then interim Privacy Commissioner of Canada, Robert Marleau, urged Parliament to reject the ID card plan (National Post, September 22, 2003, A11). His indications that the ID card plan would be too costly and bureaucratically complicated were prescient (The Windsor Star, September 19, 2003, A13). Despite her role in mobilizing the 'Maple Leaf' permanent resident card, Customs and Revenue Minister Elinor Caplan had flatly refuted the idea of a biometric national ID card (Calgary Herald, November 18, 2002, A6). Coderre's ID card plan that received a rough ride in the House of Commons from the very beginning (The Gazette, February 7, 2003, A13; The Gazette, November 19, 2002, A13).

At the same time that Coderre was indicating to a Citizenship and Immigration Consultation Forum in Ottawa that biometric national ID cards in Canada were inevitable (The Gazette, October 9, 2003, A13), the Standing Committee on Citizenship and Immigration released its report. Having met with 48 associations or individuals in Canada and another 89 internationally, the report came to a number of critical conclusions (see House of Commons, 2003a: 9-14), which are hereafter paraphrased: A national ID card does not prevent individuals from committing a terrorist act once they have the card. Moreover, if it cannot be guaranteed that the foundational documents used to obtain a national identity card are in fact legitimate, it would seem senseless to have an expensive 'proof of status' identification system in place. A much more massive and costly bureaucracy would be needed to administer the law and protect personal information. It is not impossible to counterfeit even the most technologically advanced cards, and reliance on a single card could actually increase counterfeiting and identity theft. A biometric national ID card would seem redundant given the host of other surveillance mechanisms being implemented around the globe. False rejects and false accepts are still an issue with biometric devices. Even a smile can throw off such devices. ${ }^{6}$

Moreover, the proposed national ID card system would have come with an estimated \$7 billion dollar price tag (Kamloops Daily News, November 10, 2003, B2). In the House of Commons, Canadian Alliance MP Diane Ablonczy commented that the cost of the card could finance the entire immigration system for 20 years (Guardian, October 8, 2003, A5).

\footnotetext{
${ }^{6}$ It is for this reason that the International Civil Aviation Organization (ICAO) introduced new specifications for passport photos to 188 member states around the world (Edmonton Journal, August 27, 2003, A2). Neutral expressions increase the reliability of facial recognition systems. It must also be noted that eye, fingerprint, and handprint forms of biometric recognition technologies have higher reliability rates.
} 
NDP MP Pat Martin, a member of the House of Commons Standing Committee on Citizenship and Immigration, called it "a boondoggle in the making" (Toronto Star, October 7, 2003, A6). Coderre was quick to downplay the report in the media. Despite Coderre's efforts, this report seemed to mark the end of his biometric national ID card dream.

In the summer of 2004, however, the American Association of Motor Vehicle Administrators (AAMVA), a quasi-governmental body whose members are mainly state and provincial ministries of transportation, finished the first stage of a multi-year evaluation to measure whether a common biometric license could be implemented across AAMVA jurisdictions (National Post, July 8, 2004, A4). These jurisdictions include Canadian provinces. The biometric license would act as a sort of pan-American biometric national ID card in the sense that the information subjects would still be represented on the basis of national identification, but their data would also be accessible by a host of extraCanadian agents and agencies. The move came at the same time that the Ontario government suggested it might merge health and drivers' information in a single biometric ID card (The Ottawa Citizen, July 8, 2004, A1). The debate over a national ID card system and/or similar systems in Canada is far from over.

\section{Making Sense of the Debate}

Colin J. Bennett (1997) has developed four hypotheses for trying to understand the pattern of identity card adoption and non-adoption in advanced industrial states. First, he argues that ID cards require continuous bureaucratic cooperation over data sharing and processing. New technologies make this sort of cooperation much easier. Second, national ID cards are likely to be adopted where policy-making procedures are more centralized. The federal structure of states such as Canada, Australia, and the U.S.A. goes some way to explaining why biometric ID cards have not been adopted in these countries until now: the events of 9/11 had a centralizing effect on security, defense, and im/migration policy, suspending the separation of administrative powers in this regard. Third, ID cards may be prevalent where private sector influence is more apparent. Certainly the commitment to biometric technologies in the U.S. - Canada Smart Border/30 Point Action Plan (The White House, 2001) and the Securing an Open Society (Privy Council Office of the Government of Canada, 2004) documents would imply a strong private/public sector rapport. Trade associations, such as the Toronto-based Advanced Card Technology Association of Canada (2005), act as de facto lobby groups, pressuring government to buy products. Finally, the pre-existing legacies of past surveillance policies should not be underplayed. That the UK employed national ID cards during WWI and WWII and Canada did not goes some way to explaining why a biometric national ID card proposal is now being ushered through the UK House of Commons but the same idea has failed in Canada. When an existing card surveillance infrastructure does not exist, cost also 
becomes an issue.

The practicalities of identity card adoption/non-adoption are important for understanding the recurring debates over national ID cards. Sometimes the debate polarizes. At other times, 'national' and 'special' interests converge and agree upon specific policy issues. National ID card adoption can be the outcome. Many policy-makers and government officials view biometric national ID cards as necessary to control unmanageable levels of $\mathrm{im} /$ migration flows. The hypotheses stated above regarding adoption/non-adoption also suggest a larger trend regarding surveillance and citizenship policies in liberal democracies. State politics have undergone a transformation since the 1970s. The 'New Right Project' that has replaced the Keynesian welfare state (i.e. globalization-fromabove) is an ". . . economic philosophy that calls for cuts to government spending...the restructuring of core areas of the welfare state . . to make them more cost sensitive and accountable to the logic of the marketplace" (Knight, 1998:106). Who benefits from this reorganization of capital, and how does it affect the state? Whose security is enacted by the adoption of 'proof of status' ID card technologies? Does the implementation of surveillance measures in the name of national security jeopardize other forms of security that sustain life inside state forms of political association?

\section{Securing Citizenship vs. the Securitization of Citizenship}

The issue of citizenship and its connections with intensified state surveillance is undertheorized and meagerly researched. Citizenship, traditionally conceived, is membership within an internationally recognized bordered territory where the citizen-subject is accorded certain rights if a state agency recognizes the citizen-subject as such. In general terms, surveillance is "any collection and processing of personal data . . for the purposes of influencing or managing those whose data have been garnered" (Lyon, 2001: 2; Giddens, 1981: 5, 1991: 15). In relation to the state, surveillance is better understood as the means by which centralized and centralizing organizations keep track of and construct citizens (Zureik, 2001). Nation-states, in particular, must codify the characteristics of their imagined community in order to develop "the capacities necessary to monopolize the authority to regulate movement" (Torpey, 2000:7). The concentration of political authority in the bureaucratic/information state is a precondition for universal citizenship rights (Dandeker, 1990: 217). However, administrative forms of surveillance do pre-date the formation of liberal-democratic nation-states, and it is hard to see early forms of censustaking and civil registration as overt means of social control (Higgs, 2001). Nevertheless, surveillance and citizenship are interrelated. Moreover, while citizenship policies are reconstituted when governments change, citizenship itself is not reducible to government goods.

From the liberal-democratic perspective, surveillance determines how states identify who 
to accord citizenship rights to. This is especially true of the welfare state, that historical spatialization of sovereignty in which citizenship became a form of entitlement (Bell, 1976). But this is equally true of the post-welfare (read neo-liberal) state: our current spatialization of sovereignty in which citizenship is still a form of entitlement, except that the entitlement is not extended to all who struggle for it who need it. Despite the continuing existence of the state as a form of political association and administration, it can no longer be argued that claims to citizenship are best achieved via the sovereign state (also see Beck, 1992). As Bryan Turner (1990: 199) puts it, narrowly associating citizenship with the sovereign state or other ruling class strategies "precludes, or restricts, any analysis of citizenship from below as a consequence of social struggles over resources."

T.H. Marshall's seminal work in the area of citizenship studies is characteristic of a view that associates citizenship with the Westphalian state system (Kymlicka and Norman, 1995). In Marshall's (1950: 8) historical account of modern citizenship, he asserts, "the inequality of social class may be acceptable provided the equality of citizenship is recognized." For Marshall, the modern polity has been shaped by the successive development of civil, political, and social rights, all of which constitute citizenship rights. Civil rights refer to equality before the law. Political rights refer to enfranchisement and the right to organize political parties. Social rights refer to welfare rights: "the provision of 'social services', unemployment benefit and sickness pay" (Giddens, 1981: 227). Marshall saw social rights in particular as a means of "eroding the most glaring inequalities of modern capitalism and of building social solidarity beyond the confines of ethnic or class particularisms" (Brodie, 2002: 380). Social rights after WWII became associated with the sort of security citizens could expect from their states, as states could no longer realistically protect their citizens from outside risks. The globalization of risk thus proves the artificiality of Marshall's civil-political-social triad and reveals how contemporary social life involves experiences that subsume and mix Marshall's dimensions of citizenship (Urry, 2000:69). Terrorism is only one of these risks. The political and socio-cultural fields have changed dramatically since Marshall's time, and the universalizing logic of citizenship characteristic of the welfare state has been problematized. A Marshallian approach is, therefore, limited in interpreting the relationship between new state surveillance measures and citizenship.

The concomitant emergence of neo-liberal and neo-conservative ideology after the 1973 oil crisis and ensuing recession greatly affected citizenship, governmental responses to it, and government itself. Power shifted up to transnationals, over to the private sector, and down to the local (Brodie, 2000: 110; Sassen, 1996). The citizenship concept is now contested in the literature (see Mann, 1987; Turner, 1993), and it is possible to speak of ecological, technological, urban, minority, and sexual citizenships, among others. 
Defining citizenship solely is relation to nationality, sovereignty, or the nation-state is empirically passé (Delanty, 2001). Though new surveillance projects post-9/11 indicate a marked return to the sovereign capabilities of the nation-state over the individual, the relationship between citizenship and surveillance does not exist as it did before the transformations of the late 20th and early 21 st centuries. Risk technologies like biometrics are very much implicated in this transformation of government.

Concerned with how new biometric technologies and the "securitization of the inside" post-9/11 are affecting access to citizenship rights, Benjamin Muller (2004) suggests that we are witnessing a shift from a politics of citizenship to a politics of identity management. The uniform social citizenship that was the objective of the citizen-forming strategies of the 20th century is jeopardized by the state's application of biometrics - technologies which are manifestations of a new culture of world-wide risk management. By shifting the emphasis of identity politics from identity to authentification, biometric technologies disguise and advance the restrictive aspects of contemporary securitized citizenship (Muller, 2004: 286; Lyon, 2003a: 163). In the unending 'War on Terror', biometric 'proof of status' technologies can mask the discriminatory character of the securitization of citizenship in a professional and scientific discourse (Muller, 2004: 284). Identity management strategies are less concerned with origin than with discriminating between qualified and disqualified bodies vis a vis biometric identifiers. Persons fleeing their home countries for political or economic reasons will experience difficulties seeking asylum in host countries if they have not attained one of these "proof of status" devices.

The relationships between biometric national ID cards and citizenship are multiple. First, and most pertinently, entitlement to and actualization of basic citizenship rights may soon be impossible without possession of a biometric national ID card and/or similar "proof of status" technology. Second, the biometric function of ID cards challenges theorists to rethink modern ontologies of the body, information, and the relationship of these ontologies to the broader issues of security and border politics (van der Ploeg, 2003). Under these conditions, and third, technological citizenship is not simply about how to best harness new technologies in democratic ways or how to limit technologies that infringe on civil rights. Approached another way, technological citizenship is also about limiting the use of technologies that have the potential to subordinate portions of the population (Isin and Wood, 1999: 113; Lyon, 2003a: 160). For these reasons, policymakers should turn their attention to how information and communication technologies affect the relationships among nation-states, surveillance, and citizenship.

The recurring interest in and widespread adoption of national ID cards partially substantiates Gary Marx's (1988) claim that new surveillance technologies trigger a shift from targeting specific suspects to categorical suspicion. At the same time, national 
security practices are legitimized by constructing ethno-cultural minorities, political foes, and non-citizens as security risks, and thus work to exacerbate anxiety concerning $\mathrm{im} /$ migration flows. Research has shown that since 1999 CanWest Communications in particular has published positions more unfavorable towards Muslims than have other mass media ventures (Helley, 2004). Hate crimes against Muslims were rampant in America post-9/11 (Ahmad, 2002). The kidnapping of Maher Arar by United States government officials who then sent him to Syria to be interrogated and tortured is perhaps the definitive manifestation of the clandestine profiling of Muslims and other "persons of interest" in North America (Whitaker, 2003). In Canada, not all persons share the same probability of being classified a risky non-citizen, and refugee claimants in particular are vulnerable to these sorts of profiling.

"Proof of status" surveillance technologies such as biometric national ID cards threaten the very core of the citizenship provisions that are supposed to be sacred in liberal democracies. Such technologies in no way impede the global crisis of stateless persons. We are not naively advocating a return to the liberal welfare state of decades past as a remedy to this crisis, as it has been demonstrated that the liberal welfare state is only capable of surface reallocations of economic goods and surface reallocations of respect to existing identity groups (Fraser, 1997). Rather, we are arguing that application of surveillance technologies in the areas of border security and im/migration today confronts us with new questions - questions that are inherently political. Most importantly, the question "Who has the legitimate authority to collect our personal information and administer us across space and time based on that information?" must not fall prey to liberalist-doxic common-sense. Answers to these questions are best addressed by thinking outside the conceptual confines of the nation-state.

The way in which people understand their conditions of existence is a site of struggle where those conditions can be either reproduced or transformed. Inverting Hobbes' (1952: 153 ) infamous assertion that the "the essential rights of sovereignty" must be obeyed at all costs or else "every man [sic] returneth into the condition and calamity of war with every other," we might ask what legitimacy do state agencies have if they cannot internally protect the rights and welfare of their current and future citizens? If the ability of citizens to access citizenship rights is jeopardized by state introduction of technologically advanced surveillance devices, then does it make sense to understand the state as the legitimate unit of sovereignty?

State sovereignty is historically constituted and variable, so to take sovereignty for granted is to take politics for granted as well (Walker, 2000; 1993). Rapid modernization is jeopardizing its own basic principles. It cannot be claimed, then, that the expansion of citizenship goes neatly hand in hand with the processes of modernization. The introduction 
of biometric national ID cards and other "proof of status" surveillance technologies threatens the very spatializations of modern sovereignty these technologies purport to defend in the name of national security (Huysmans, 2004). To sit back and watch while states retract citizenship rights is to forsake the struggles of those who have fought for social welfare, for enfranchisement, and for the other universal rights that are associated with what it means to be a citizen in a liberal democracy. More significantly, if it is the case that advanced post-industrial states are moving towards identity management by means of biometric national ID cards and similar devices (a securitization rather than a securing of citizenship), then people must initiate local and participatory means of redressing economic and cultural injustices that exceed the tightfisted direction in which liberal democracies have been headed for some time. Indeed, the language of rights and state-based citizenship is not sufficient for those on the left interested in a politics beyond the liberal democratic state (Vahabzadeh, 2000; 2003). That "proof of status" state surveillance devices can restrict access to citizenship while persisting under the rhetorical language of rights speaks to the contradictions that are the life-blood of liberal democracy. 


\section{REFERENCES}

Adelman, H. 2002. "Refugees and Border Security Post-September 11." Refuge, Vol. 20, No. 4, pp. 5-14.

Agar, J. 2001. "Modern Horrors: British Identity and Identity Cards." In Documenting Individual Identity: The Development of State Practices in the Modern World. J. Caplan and J. Torpey (eds.). Princeton: Princeton University Press, pp. 101-120.

Ahmad, M. 2002. "Homeland Insecurities: Racial Violence the Day After September 11." Social Text, Vol. 20, No. 3, pp. 101-115.

Beck, U. 1992. Risk Society: Towards a New Modernity. London: Sage Publications.

Beck, U., Bonss, W. and C. Lau. 2003. "The Theory of Reflexive Modernization: Problematic, Hypotheses, and Research Programme." Theory, Culture \& Society, Vol. 20, No. 2, pp. 1-33.

Bell, D. 1976. The Cultural Contradictions of Capitalism. New York: Basic Books.

Bennett, C.J. 1997. 'Pick a Card: Surveillance, Smart Identification, and the Structure of Advanced Industrial States." Paper presented at the Canadian Political Science Association Annual Meeting, St. John's, Newfoundland, June 8th, 1997.

Biersteker, T.J. 2003. "The Rebordering of North America: Implications for Conceptualizing Borders After September 11." In The Rebordering of North America: Integration and Exclusion in a New Security Context. P. Andreas and T.J. Biersteker (eds.). New York: Routledge, pp. 153-167.

Bowker, G.C. and S.L. Star. 1999. Sorting Things Out: Classification and Its Consequences. Cambridge, Mass.: MIT Press.

Brodie, J. 2002. "Citizenship and Solidarity: Reflections of the Canadian Way." Citizenship Studies, Vol. 6, No. 4, pp. 377-394.

Brodie, J. 2000. "Imagining Democratic Urban Citizenship." In Democracy, Citizenship, and the Global City. E.F. Isin (ed.). London: Routledge, pp. 110-128.

Czegledy, N. and A.P. Czegledy. 2002. "The Body as Password: Biometrics and Corporeal Dispossession." Filozofski Vestnik, Vol. 23, No. 2, pp. 75-92.

Dandeker, C. 1990. Surveillance, Power, and Modernity: Bureaucracy and Discipline from 1700 to the Present Day. New York: St. Martin's Press.

Delanty, G. 2001. Citizenship in a Global Age: Society, Culture, and Politics. Buckingham: Open University Press.

Eaton, J.W. 1986. Card-Carrying Americans: Privacy, Security, and the National ID Card Debate. New Jersey: Rowman and Littlefield Publishers.

EKOS Research Associates, Inc. 2003. "Canadian Attitudes Towards Biometrics and Document Integrity." Paper presented at the Citizenship and Immigration Forum, Ottawa. October 7-8, 2003.

Etzioni, A. 1999. The Limits of Privacy. New York: Basic Books. 
Foucault, M. 1978. The History of Sexuality. Volume 1: An Introduction. New York: Pantheon.

Fraser, N. 1997. "From Recognition to Redistribution? Dilemmas of Justice in a 'Postsocialist' Age." Justice Interruptus. New York Routledge, pp. 11-39.

Giddens, A. 1991. Modernity and Self-Identity: Self and Society in the Late Modern Age. Cambridge, UK: Polity Press.

Giddens, A. 1981. A Contemporary Critique of Historical Materialism: Vol. I Power, Property, and the State. London: The Macmillan Press Ltd.

Gill, P. 2003. "Democratic and Parliamentary Accountability of Intelligence Services after September 11th." Working Paper No. 103: Geneva Centre for the Democratic Control of Armed Forces.

Haggerty, K.D. and R.V. Ericson. 2000. “The Surveillant Assemblage.” British Journal of Sociology Vol. 51. No. 4, pp. 605-622.

Hier, S.P. 2003. "Probing the Surveillant Assemblage: On the Dialectics of Surveillance Practices as Processes of Social Control." Surveillance and Society, Vol. 1, No. 3, pp. 399-411.

Higgs, E. 2001. "The Rise of the Information State: the Development of Central State Surveillance of the Citizen in England, 1500-2000." Journal of Historical Sociology, Vol. 14, No. 2, pp. 175-196.

Helly, D. 2004. “Are Muslims Discriminated Against in Canada Since September 2001?” Canadian Ethnic Studies, Vol. XXXVI, No. 1, pp. 24-48.

Hobbes, T. 1952. Leviathan, or, Matter, Form, and Power of a Commonwealth Ecclesiastical and Civil. New York: William Benton.

Home Office. 2004. "David Blunkett: National ID Card Scheme is the Key to the UK's Future." Website: http://www.homeoffice.gov.uk/n_story.asp?item_id=918. Accessed March 3, 2005.

House of Commons. 2003a. "A National Identity Card for Canada? Report of the Standing Committee on Citizenship and Immigration." House of Commons Canada. Joe Fontana, M.P., Chair.

House of Commons. 2003b. "Taking the Necessary Measures to Enhance the Integrity of the Social Insurance Number: a Review of the Action Plan." House of Commons Canada. Judi Longfield, M.P., Chair.

Huysmans, J. 2004. "Minding Exceptions: The Politics of Insecurity and Liberal Democracy." Contemporary Political Theory, Vol. 3, No. 3, pp. 321-341.

Isin, E.F. and P.K. Wood. 1999. Citizenship and Identity. London: Sage.

Kim, M.C. 2004. "Surveillance Technology, Privacy and Social Control." International Sociology, Vol. 19, No. 2, pp. 193-213.

Knight, G. 1998. "Hegemony, the Media and New Right Politics: Ontario in the Late 1990s." Critical Sociology, Vol. 24, No. 1-2, pp 105-129. 
Kymlicka, W. and W. Norman. 1995. "Return of the Citizen: A Survey of Recent Work on Citizenship Theory." In Theorizing Citizenship. R. Beiner (ed.). Albany: State University of New York, pp. 282-322.

Longman, T. 2001. "Identity Cards, Ethnic Self-Perception, and Genocide in Rwanda." In Documenting Individual Identity: The Development of State Practices in the Modern World. J. Caplan and J. Torpey (eds.). Princeton: Princeton University Press, pp. 345-357.

Lyon, D. 2004. "Identity Cards: Social Sorting by Database.” Oxford Internet Institute, Internet Issue Brief No. 3, November. Website: http://www.oii.ox.ac.uk/resources/. Accessed March 3, 2005.

Lyon, D. 2003a. Surveillance after September 11. Cambridge: Polity Press.

Lyon, D. 2003b. "Technology vs Terrorism: Circuits of City Surveillance since September 11th." International Journal of Urban and Regional Research, Vol. 27, No. 3, pp. 666-678.

Lyon, D. 2001. Surveillance Society: Monitoring Everyday Life. Buckingham, UK: Open University Press.

Lyon, D. 1993. "British Identity Cards: 'The Unpalatable Logic' of European Integration?" The Political Quarterly, Vol. 62, No. 3, pp. 377-385.

Lyon, D. and D. Wood. Forthcoming. "Surveillance in Japan, Before and After September 11." Under submission with Urban Studies.

Mann, M. 1987. "Ruling Strategies and Citizenship.” Sociology, Vol. 21, No. 3, pp. 339-354.

Marshall, T.H. 1950. Citizenship and Social Class. Cambridge: Cambridge University Press.

Marx, G.T. 1988. Undercover: Police Surveillance in America. Berkeley: University of California Press.

Muller, B.J. 2004. “(Dis)Qualified Bodies: Securitization, Citizenship and Identity Management.”. Citizenship Studies, Vol. 8, No. 3, pp. 279-294.

Privacy International. 2005. 'UK House of Commons Approves ID Card'. Date Accessed: February $28,2005$.

Public Policy Forum. 2003. "Biometrics: Implications and Applications for Citizenship and Immigration." POLLARA. Background paper prepared for the Citizenship and Immigration Canada Forum.

Sassen, S. 1996. Losing Control? Sovereignty in the Age of Globalization. New York: Columbia University Press.

Schulhofer, S.J. 2002. The Enemy Within: Intelligence Gathering, Law Enforcement, and Civil Liberties in the Wake of September 11. New York: Century Foundation Press.

Shearman, P. and M. Sussex. 2004. “America and Europe After 9/11.” In European Security After 9/11. P. Shearman and M. Sussex (eds.). Aldershot: Ashgate, pp. 51-68.

Stadler, F. and D. Lyon. 2003. "Electronic Identity Cards and Social Classification." In Surveillance as Social Sorting: Privacy, Risk, and Digital Discrimination. D. Lyon (ed.). London: Routledge. 
Stevens, J. 2001. Book review of Jeremy Harding's The Uninvited; Michael Dummett's On Immigration and Asylum; and Teresa Hayter's Open Borders. New Left Review, Vol. 12, November-December, pp. 152-159.

Toronto-based Advanced Card Technology Association of Canada. http://www.actcda.com/. Last accessed Saturday October 1, 2005.

Torpey, J. 2000. The Invention of the Passport: Surveillance, Citizenship, and the State. Cambridge: Cambridge University Press.

Treiman, D.J. and X. Wu. 2004. "The Household Registration System and Social Stratification in China: 1955-1996.” Demography, Vol. 41, No. 2, pp. 363-384.

Turner, B.S. 1993. "Contemporary Problems in the Theory of Citizenship." In Citizenship and Social Theory. B.S. Turner (ed.). London: Sage, pp. 1-18.

Turner, B.S. 1990. "Outline of a Theory of Citizenship.” Sociology, Vol. 24, No. 2, pp. 189-217.

Urry, J. 2000. "Global Flows and Global Citizenship." In Democracy, Citizenship, and the Global City. E.F. Isin (ed.). London: Routledge, pp. 62-78.

Vahabzadeh, P. 2003. Articulated Experiences: Towards a Radical Phenomenolgy of Contemporary Social Movements. Albany: State University of New York Press.

Vahabzadeh, P. 2000. "Technological Liberalism and the Anarchic Actor." In Anarcho-Modernism. Toward a New Radical Theory in Honour of Jerry Zaslove. I. Angus (ed.). Vancouver: Talon Books, pp. 341-350.

van der Ploeg, I. 2003. "Biometrics and the body as information: Normative issues of the socio-technical coding of the body." In Surveillance as Social Sorting: Privacy, Risk, and Digital Discrimination. D. Lyon (ed.). London, UK: Routledge, 57-73.

Walker, R.B.J. 2000. "Europe is not Where it is Supposed to Be." International Relations Theory and the Politics of European Integration: Power, Security, and Community. London: Routledge, pp. 14-32.

Walker, R.B.J. 1993. Inside/Outside: International Relations as Political Theory. Cambridge: Cambridge University Press.

Wang, F. 2004. "Reformed Migration Control and New Targeted People: China's Hukou System in the 2000s." The China Quarterly, No. 177, pp. 115-132.

Weber, M. 1983. “The Nature of Modern Capitalism'. In Max Weber on Capitalism. Bureaucracy and Religion: A Selection of Texts. S. Andreski (ed.). London: George Allen \& Unwin.

Weber, M. 1968. Volume 3 of Economy and Society: An Outline of Interpretive Sociology. G. Roth and C. Wittich (eds.). New York: Bedminister Press.

Whitaker, R. and G. Marcuse. 1994. Cold Ware Canada: The Making of a National Insecurity State, 1945-1957. Toronto: University of Toronto Press.

Whitaker, R. 2005. "A Faustian Bargain? America and the Dream of "Total Information Awareness"”. In The New Politics of Surveillance and Visibility. K. Haggerty and R.V. Ericson (eds.). Toronto: University of Toronto Press. 
Whitaker, R. 2003. “After 9/11: a Surveillance State?” In Lost Liberties: Ashcroft and the Assault on Personal Freedom. C. Brown (ed.). New York: New Press.

Williams, S.J. 2004. "Bioattack or Panic Attack? Critical Reflections on the Ill-logic of Bioterrorism and Biowelfare in Late/Postmodernity." Social Theory and Health, Vol. 2, No. 1, pp. 67-93.

Zureik, E. 2001."“Constructing Palestine through Surveillance Practices." British Journal of Middle Eastern Studies, Vol. 28, No. 2, pp 205-227.

Zureik, E. and K. Hindle. 2004. "Governance, Security, and Technology: The Case of Biometrics." Studies in Political Economy, Vol. 73, Spring/Summer, pp. 113-137.

\section{Government Publications}

Beyond the Numbers: The Future of the Social Insurance Number System in Canada. 1999. The Standing Committee on Human Resource Development: Ottawa.

Building a Nation. 2002. Standing Committee on Citizenship and Immigration report. http://www.parl.gc.ca/InfoComDoc/37/1/CIMM/Studies/Reports/cimmrp04-e.htm. Last accessed Saturday October 1, 2005.

National Intelligence Reform Act of 2004. 2004. Congress, United States Government. http://www.apcointl.org/about/gov/documents/National_Intelligence_Reform_Act.htm. Last accessed Saturday October 1, 2005.

9/11 Recommendations Implementation Act. 2004. Congress United States Government. ht t p ://www.gpoaccess.gov/serialset/creports/pdf/108796 /titlevii_implement_911_recs.pdf\#search='9\%2F11\%20Recommendations \%20Implementation'. Last accessed Saturday October 1, 2005.

Our Shared Border Accord. 1995. Bill Clinton, United States Government, and Jean Chretien, Federal Government of Canada.

Privy Council Office of the Government of Canada. 2004. 'Securing an Open Society :Canada's National Security Policy'. http://publications.gc.ca/control/publicationInformation? searchAction=2\&publicationId=259262. Date Accessed: February 24th, 2005.

The Patriot Act. 2001. Department of Justice, United States Government. $\mathrm{ht} \mathrm{tp://frwebgate.access.gpo.gov/cg} \mathrm{i-bin/getdoc.cgi?}$ dbname $=107$ cong_public_laws\&docid=f:pub1056.107.pdf. Last accessed Saturday October 1,2005 .

The White House. 2001. 'U.S. - Canada Smart Border/30 Point Action Plan Update'. Website: http://www.whitehouse.gov/news/releases/2002/12/20021206-1.html Date Accessed: November 23, 2004.

\section{Media Articles}

Calgary Herald, February 6, 2003. A1. 'ID cards pitched as fraud fighter'. Author: Jim Bronskill. 
Calgary Herald, November 18, 2002. A6. 'Caplan denies ID card suggestion'. Author: Newswire.

Daily News, April 19, 2003. A2. 'Coderre seeks toolbox: Inclusive immigration strategy would include community'. Author: Robin Arthur.

Edmonton Journal, August 27, 2003. A2. 'Its official...'. Author: Elizabeth Thompson.

Edmonton Journal, July 27, 2003. A6. 'Biometric ID card support will slip - report'. Author: Jack Aubry.

Edmonton Journal, June 5, 1994. B4. 'Canadian ID card in planning stage; Holders could bypass long lineups'. Author: Ron Eade.

The Gazette, November 21, 2003. A27. 'ID cards are an open invitation to discrimination'. Author: Janet Bagnall.

The Gazette, October 9, 2003. A13. 'Biometrics use needs safeguards: Coderre: But high-tech ID is just a matter of time, he says'. Author: Elizabeth Thompson.

The Gazette, February 7, 2003. A13. 'Coderre gets a rough ride on national ID card plan'. Author: Elizabeth Thompson.

The Gazette, November 19, 2002. A13. 'Coderre pushes his high-tech ID card: Idea roundly criticized by most parties in House'. Author: Elizabeth Thompson.

Guardian, October 8, 2003. A5. 'National ID card could cost billions, says report'. Author: Newswire.

Kamloops Daily News, November 10, 2003, B2. 'Coderre defends national ID card'. Author: Jim Brown.

National Post, July 8, 2004. A4. 'North American ID card proposed: Biometric licence database could cover 300 million people'. Author: Sarah Staples.

National Post, September 22, 2003. A11. 'Questioning Coderre'. Author: Editorial.

National Post, November 15, 2002. A8. 'Minister pushes for border ID cards: No mention of birthplace on 'maple leaf' ID'. Author: Bill Curry.

National Post, April 24, 1999. D3. 'Who stands on guard for Canada? Officials need to run a thorough check on all 'refugees". Author: Diane Francis.

The Ottawa Citizen, July 8, 2004. A1. 'Licensing group wants just one biometric ID for whole continent'. Author: Sarah Staples.

The Ottawa Citizen, March 19, 2003. A11.'Privacy czar condemns biometric ID card'. Author: Elizabeth Thompson.

The Ottawa Citizen, February 14, 1996. A10. 'Not-so-smart card plan’. Author: Newswire.

Times-Colonist, April 11, 2004. D4. 'Is a National ID Card the Smart Thing to Do?' Author: Jim Hume.

Times-Colonist, July 15, 1995. A1. 'Privacy commissioner hopes Ontario's plans for ID fizzle'. Author: Bruce Phillips. 
Toronto Star, October 7, 2003. A6. 'ID cards seen as 'a slippery slope'; National plan would be expensive, ineffective, report warns Commons committee to offer long list of privacy concerns'. Author: Bruce Campion-Smith.

Toronto Star, Jul 14, 1995. A12. 'Privacy watchdog criticizes Harris' suggestion of ID card'. Author: David Vienneau.

The Windsor Star, September 19, 2003. A13. 'National ID card tab: \$5B; Privacy commissioner urges Ottawa to cancel plans'. Author: Newswire.

The Windsor Star, July 25, 2003. B1. 'Martin questions need for ID cards'. Author: Newswire.

The Windsor Star, May 25, 1999. A8. 'National identity card'. Author: Diane Francis.

\section{CONGRATULATORY NOTE}

Meg Luxton of York University, a member of the Society for Socialist Studies has been given the Sarah Shorten Award for outstanding achievements in the promotion of the advancement of women in Canadian universities and colleges. This was awarded to her by the Canadian Association of University Teachers.

Scholarship, teaching, leadership and activism have been the mainstay of Luxton's life. She is one of the founders of the graduate programme in women's studies at York, and has been key to furthering feminist scholarship. Her half-dozen books, as well as numerous articles and book chapters, cover a wide range of topics that advance the cause of women.

For more than 30 years, Luxton has given tirelessly of her time and energy, from community-based activism to organizational leadership in her faculty association, to the fight for women's rights. Luxton received the award in Ottawa on April 29, 2005.

The award is dedicated to the late Sarah Shorten, who served as vice-president and president of CAUT in the 1980s. 